\title{
Resepsi Audiens atas Kekerasan Seksual Terhadap Pemberitaan Korban Pelecehan Seksual Baiq Nuril
}

\author{
Miranda Ainin Prihandini \\ Program Studi Ilmu Komunikasi, Universitas Muhammadiyah Surakarta, Indonesia \\ mirandaaininprihandini@gmail.com \\ Diserahkan: 12 April 2020; Direvisi: 5 Maret 2021; Diterima: 13 Maret 2021
}

\begin{abstract}
This study tries to investigate how the audience reception for sexual violence regarding the news of victim of sexual harassment Baiq Nuril. The issue of sexual violence in the media is interesting because through reporting by the media can bring up the meaning of the audience. Audiences have their respective meanings of sexual violence in this case as well as what is happening in Indonesia now. The purpose of this study is to find out how the audience reception for sexual violence regarding the news of victims of sexual harassment Baiq Nuril. This study uses a critical paradigm from Hall's thinking by using qualitative methods and descriptive research types. The sampling technique used are purposive and snowball sampling. The results of this study indicate that the informants have various meanings regarding the coverage of the Baiq Nuril case. The informant agreed that the media placed Baiq Nuril as a victim of sexual violence. Informants have the meaning of sexual violence based on their respective backgrounds, namely perspective, education, gender, and their social role. The position of women in cases of sexual violence as a vulnerable party because women are considered as objects and even triggers.

Keywords: Audience Reception, Baiq Nuril Nerws, Media, Sexual Violence.
\end{abstract}

\begin{abstract}
Abstrak
Penelitian ini ingin mengetahui bagaimana resepsi audiens atas kekerasan seksual terhadap pemberitaan korban pelecehan seksual Baiq Nuril. Isu kekerasan seksual di media menarik untuk diteliti karena melalui pemberitaan yang dilakukan oleh media dapat memunculkan pemaknaan dari audiens. Audiens memiliki pemaknaan mereka masing-masing atas kekerasan seksual dalam kasus ini maupun yang terjadi di Indonesia sekarang ini. Tujuan dari penelitian ini yaitu bagaimana resepsi audiens atas kekerasan seksual terhadap pemberitaan korban pelecehan seksual Baiq Nuril? Penelitian ini menggunakan paradigma kritis dari pemikiran Hall dengan menggunakan metode kualitatif dan jenis penelitian deskriptif. Teknik sampling yang digunakan yaitu purposive dan snowball sampling. Hasil penelitian ini menunjukkan bahwa informan memiliki pemaknaan yang beragam mengenai pemberitaan kasus Baiq Nuril. Informan memiliki pemaknaan atas kekerasan seksual berdasarkan latar belakang mereka masing-masing yaitu perspektif, pendidikan, gender, dan peran sosial mereka. Berdasarkan pemaknaan informan, posisi perempuan pada kasus kekerasan seksual sebagai pihak yang rentan karena perempuan dianggap sebagai objek bahkan pemicu. Kata Kunci: Berita Baiq Nuril, Kekerasan Seksual, Media, Resepsi Audiens.
\end{abstract}




\section{PENDAHULUAN}

Ramainya pemberitaan mengenai kasus Baiq Nuril sebagai korban pelecehan seksual memberikan tanggapan, kritik, dan menjadi perbincangan tersendiri bagi masyarakat. Pemberitaan tersebut menjadi sorotan berbagai media massa seperti pemberitaan di televisi, website berita online, bahkan program gelar wicara (talkshow) di televisi. Kasus yang terjadi pada tahun 2012 ini, di mana inisial M selaku Kepala Sekolah SMA Negeri 7 Mataram yang kerap kali menelepon Baiq Nuril yang saat itu menjadi guru honorer dan menceritakan mengenai pengalaman hubungan seksualnya dengan wanita lain (Kompas.com, 2019b). Baiq Nuril merekam percakapan telepon tersebut yang akan dijadikan sebagai bukti terjadinya pelecehan seksual secara verbal yang dialaminya (Kompas.com, 2019b).

Tersebarnya rekaman tersebut membuat M tidak terima dan akhirnya melaporkan Baiq Nuril (Kompas.com, 2019b). Mahkamah Agung (MA) menyatakan Baiq Nuril bersalah telah melanggar pasal 27 ayat 1 Undang-Undang tentang Informasi dan Transaksi Elektronik (UU ITE) karena menyebarkan rekaman telepon, padahal yang menyebarkan rekaman tersebut bukanlah dirinya sendiri namun rekan kerjanya (Kompas.com, 2019b).

Setelah diputuskan bersalah, Baiq Nuril mengajukan permohonan peninjauan kembali (PK) atas putusan MA yang telah ditetapkan sebelumnya. Pada akhirnya, MA menolak PK yang telah diajukan Baiq Nuril (Metrotvnews, 2019). MA menilai perkara dalam permohonan PK tersebut berbeda dengan perkara dugaan pelecehan seksual yang dialaminya. MA hanya mengadili perkara yang menjadikan Baiq Nuril sebagai terdakwa kasus UU ITE (Kompas.com, 2019a).

Selanjutnya, Baiq Nuril memohon amnesti kepada Presiden Joko Widodo karena tidak mendapatkan keadilan dalam PK yang diajukannya. Amnesti menjadi satu-satunya jalan agar Baiq Nuril dibebaskan atas perkara tersebut. Perjuangan Baiq Nuril akhirnya membuahkan hasil karena Presiden Joko Widodo mengeluarkan surat pertimbangan amnesti dan disepakati oleh seluruh anggota DPR dalam rapat paripurna pada 25 Juli 2019 (Kompas.com, 2019b).

Menurut Equal Employment Opportunity Commission (EEOC) Amerika Serikat, pelecehan seksual merupakan pengalaman sosiologis berdasarkan perilaku seksual yang tidak diinginkan, ofensif, dan mengancam di tempat kerja. Berdasarkan definisi tersebut, maka terdapat tiga kategori utama pelecehan seksual yaitu pemaksaan seksual, perhatian seksual yang tidak diinginkan, dan pelecehan gender (Keplinger, Johson, Kirk, \& Barnes, 2019).

Pada kasus tersebut, Baiq Nuril yang menjadi korban tidak melaporkan pelecehan seksual di ranah komunitas yang terjadi di lingkungan kerja tersebut dikarenakan takut akan kehilangan pekerjaan sebagai guru honorer pada saat itu (Metrotvnews, 2019). Budaya patriarki juga turut andil melatarbelakangi dalam kasus ini di mana adanya relasi kuasa antara laki-laki yang memiliki kekuasaan yaitu kepala sekolah menjadi pihak yang superior dan perempuan yang hanya sebagai guru honorer sebagai pihak inferior (Adisa, Abdulraheem, \& Isiaka, 2019).

Selain itu, Baiq Nuril yang menjadi korban pelecehan seksual secara verbal justru dilaporkan dan divonis bersalah karena melanggar UU ITE (MetroTV, 2019). Hal tersebut yang membuat hukum melakukan victim blaming. Konsep blaming the victim yaitu di mana perempuan yang disalahkan padahal perempuan tersebut merupakan korban dari suatu kasus (Astuti, Pradoto, \& Romaria, 2019). Dalam kalimat lain, perempuan dianggap sebagai pemicu perbuatan pelecehan seksual tersebut. Konsep blaming the victim juga merupakan pembenaran atas ketidakadilan dengan menemukan kesalahan pada korban yang tidak diberikan keadilan (Astuti et al., 2019). Hal tersebut yang membuat korban memilih untuk diam daripada mengambil sikap melawan atau melaporkan kasus tersebut karena dianggap menyebarkan aib sendiri. Bahkan ketika ada korban yang berani menyuarakan tindakan kekerasan atau pelecehan seksual tersebut, mereka dianggap sebagai pihak yang bersalah karena mereka sendiri yang telah memancing perbuatan tersebut (Keplinger et al., 2019).

Berdasarkan data dari Komisi Nasional Anti Kekerasan terhadap Perempuan (Komnas Perempuan) yang terdapat dalam Catatan Tahunan (CATAHU) 2020, kekerasan terhadap perempuan semakin meningkat dari tahun ke tahun. Pada tahun 2018 sebanyak 406.178 kasus dan pada tahun 2019 
meningkat sebanyak 6\% menjadi 431.471 kasus. Kekerasan terhadap perempuan terjadi dalam berbagai ranah, salah satunya di ranah publik atau komunitas. Sebanyak 58\% dari angka kekerasan terhadap perempuan di ranah publik atau komunitas pada tahun 2019 merupakan kekerasan seksual (Komnas Perempuan, 2020).

Media dalam peranannya sangat penting sebagai sumber informasi terutama dalam pemberitaan suatu kasus. Menurut Thacker (2017), melalui media dapat membentuk suatu konstruksi atas realitas dan juga dapat mengubah pemikiran audiens. Bahkan, banyak audiens yang menganggap bahwa media adalah satu-satunya sumber informasi bagi mereka (Thacker, 2017). Audiens akan memproses dan menerima apa yang mereka percaya sebagai suatu realitas setelah melalui proses yang saling berpengaruh (Nisa, 2017). Maka dari itu, seharusnya media mampu memposisikan perannya, khususnya dalam mengadvokasi kasus kekerasan terhadap perempuan agar tidak melanggengkan budaya victim blaming tanpa melihat keadilan atas realitas yang sebenarnya.

Menurut Barker, seperti yang dikutip dalam Toni \& Fajariko (2017), setiap audiens memiliki pandangan dan interpretasi mereka sendiri terhadap suatu pemberitaan. Khalayak sebagai produsen makna dalam kaitannya dengan teks, dipengaruhi oleh kompetensi kultural dan pengalaman individu yang akhirnya mereka bawa dalam teks, sehingga audiens yang terbentuk dengan cara yang berbeda akan memberikan makna yang berbeda pula (Toni \& Fajariko, 2017).

Pemberitaan mengenai kasus Baiq Nuril pada media massa televisi salah satunya yaitu pada program berita di MetroTV yang dapat diakses pada website wrwremetrotonewes.com. Terdapat sebanyak 11 video tayangan mengenai pemberitaan kasus Baiq Nuril, namun hanya 10 video yang dapat ditayangkan dalam website tersebut. Video yang terdapat pada website tersebut dipublikasikan pada tanggal 23-29 Juli 2019 dan juga disiarkan di MetroTV. Pemberitaan di MetroTV juga dapat diakses melalui channel Youtube resmi MetroTV yaitu metrotvnews, di mana pada channel tersebut terdapat sebanyak 56 video yang diunggah pada tahun 2018 dan 2019 mengenai Baiq Nuril.

Pada pemberitaan di MetroTV, kronologi kasus dijelaskan dengan detail dan cukup informatif. MetroTV juga menghadirkan secara langsung berbagai pihak terkait seperti Baiq Nuril dan kuasa hukumnya, serta menampilkan saat wawancara dengan Presiden dan Menteri Sekretaris Negara (Mensesneg), atau hanya dengan melalui sambungan telepon dengan Anggota Dewan Perwakilan Rakyat (DPR). Pada 10 video tayangan pemberitaan yang berada di website tersebut hanya menyebutkan nama dari pelaku dan tidak pernah menampilkan pelaku kekerasan seksual. Kemudian pada channel Youtube metrotvnews hanya terdapat satu dari 56 video yang menampilkan sosok pelaku kekerasan seksual tersebut.

Pemberitaan mengenai kasus Baiq Nuril pada media massa televisi lainnya yaitu pada program berita di RCTI yang juga dapat diakses pada channel Youtube RCTI Seputar iNews. Pada channel Youtube tersebut hanya terdapat sebanyak tiga video pemberitaan mengenai kasus Baiq Nuril yang diunggah pada November 2018. Pada channel Youtube Official iNews juga mengunggah sebanyak 104 video mengenai Baiq Nuril dengan sebanyak sepuluh video di antaranya yang terdapat logo RCTI. Pemberitaan yang dilakukan oleh RCTI cukup informatif dengan menyajikan informasi mengenai perkembangan kasus Baiq Nuril dengan menampilkan wawancara dengan pihak terkait sehingga memberikan penjelasan dari berbagai sisi, bukan hanya dari sisi Baiq Nuril namun juga dari sistem hukum yang berlaku di Indonesia.

Pemberitaan lain mengenai Baiq Nuril juga terdapat pada program gelar wicara (talkshow) di televisi yaitu Mata Najwa pada Trans7. Mata Najwa episode "Hukuman Salah Alamat" ini diunggah kembali pada channel Youtube Najwa Shihab dan terbagi ke dalam tujuh bagian (part) yang dipublikasikan pada tanggal 22 November 2018. Pada episode tersebut menghadirkan langsung pihakpihak terkait seperti Baiq Nuril, Kuasa Hukum Baiq Nuril, Juru Bicara Mahkamah Agung, bahkan Menteri Komunikasi dan Informatika untuk memberikan penjelasan lebih mendalam mengenai kasus tersebut. 
Pemberitaan pada Mata Najwa cukup informatif karena memberikan informasi dari berbagai pihak, baik dari pihak Baiq Nuril sendiri dan juga pihak-pihak dari pemerintah. Namun dalam tayangan tersebut tidak mendatangkan pelaku kekerasan seksual dan hanya beberapa kali disebutkan dalam kronologi kasus. Pada episode tersebut tidak hanya membahas mengenai kasus Baiq Nuril, tetapi juga membahas mengenai kasus lain yang terjerat UU ITE.

Selanjutnya, pemberitaan lain mengenai kasus Baiq Nuril terdapat pada website Kompas.com. Pada kategori regional maupun nasional dari Kompas.com, dalam mengawal berjalannya kasus tersebut cukup aktif dengan selalu memberikan informasi terbaru kepada masyarakat sejak tahun 2017 hingga berakhirnya kasus tersebut yaitu tahun 2019. Ketika mengetik kata kunci “Baiq Nuril” pada mesin pencarian yang disediakan pada website Kompas.com, Kompas.com hanya menampilkan sebanyak sepuluh teks berita saja setiap halamannya dan halaman maksimal yang ditampilkan sebanyak sepuluh halaman. Sehingga total teks berita yang dapat ditampilkan hanya sebanyak 100 teks berita. Apabila mengakses berita melalui https://wrwr.kompas.com/tag/Baiq-Nuril?sort=desc, maka akan menampilkan sebanyak 20 teks berita setiap halamannya dan halaman maksimal yang ditampilkan sebanyak 13 halaman, sehingga jumlah berita keseluruhan mengenai Baiq Nuril dari tahun 2017-2019 terdapat sebanyak 260 berita yang dapat diakses.

Kompas.com sebagai media yang cukup informatif dalam memberitakan kasus tersebut, di mana menjelaskan dari berbagai sudut pandang pihak yang terlibat dalam kasus tersebut seperti Baiq Nuril, Mahkamah Agung, bahkan Presiden. Hal tersebut menambah pengetahuan baru kepada audiens dan audiens berhak menentukan pilihannya sendiri dalam memaknai pemberitaan tersebut menggunakan sudut pandang mereka masing-masing.

Pemberitaan mengenai kasus Baiq Nuril juga memberikan anggapan tersendiri yang berbeda-beda bagi masyarakat baik pro maupun kontra. Misalnya seperti bentuk dukungan dengan adanya petisi dalam website change.org yaitu "Amnesti untuk Nuril" sebagai dorongan agar Presiden bersedia memberikan amnesti. Bahkan ada pula yang menilai sikap Baiq Nuril salah karena tidak melaporkan kasus pelecehan seksual yang dialaminya dan justru memberikan rekaman tersebut kepada rekan kerjanya. Selain itu ada juga yang lebih setuju dengan keputusan MA yang menyatakan bahwa Baiq Nuril bersalah.

Berdasarkan uraian di atas, penelitian ini menggunakan judul "Resepsi Audiens atas Kekerasan Seksual terhadap Pemberitaan Korban Pelecehan Seksual Baiq Nuril”. Masalah ini menarik dan penting untuk diteliti karena ingin mengetahui resepsi audiens atas kekerasan seksual mengenai pemberitaan kasus Baiq Nuril yang menjadi korban pelecehan seksual yang sekarang ini menjadi perbincangan yang menarik simpati dari masyarakat dan menuai banyak pro dan kontra. Audiens yang berbeda maka akan memberikan interpretasi yang berbeda juga terhadap pemberitaan kasus ini. Tujuan penelitian ini yaitu ingin mengetahui bagaimana resepsi audiens atas kekerasan seksual terhadap pemberitaan korban pelcehan seksual Baiq Nuril.

\section{KERANGKA TEORI}

\section{KEKERASAN SEKSUAL}

Menurut Komnas Perempuan (2017), pelecehan seksual termasuk salah satu bentuk dari kekerasan seksual. Tindakan pelecehan seksual ini dilakukan baik melalui sentuhan fisik maupun non-fisik. Pelecehan tersebut seperti siulan, ucapan bernuansa seksual, gerakan isyarat seksual, dan hal lainnya yang membuat korban tidak nyaman dan merasa direndahkan martabatnya (Komnas Perempuan, 2017). Perempuan yang menjadi korban kekerasan seksual sering kali diam dan tidak melaporkan kasus yang dialaminya tersebut karena korban seringkali disalahkan dan dianggap sebagai penyebab terjadinya kekerasan seksual tersebut. Hal tersebut yang membuat kekerasan seksual sulit untuk diungkap dan ditangani karena dikaitkan dengan konsep moralitas masyarakat di mana perempuan dianggap sebagai simbol kesucian dan kehormatan. Maka dari itu perempuan yang mengalami kekerasan seksual dianggap sebagai aib (Komnas Perempuan, 2017). 
Selain itu juga terdapat budaya patriarki yang melatarbelakangi kekerasan seksual terhadap perempuan. Patriarki merupakan sebuah sistem sosial yang menganggap bahwa posisi laki-laki sebagai pemegang kekuasaan dan lebih dominan dibangingkan perempuan (Adisa et al., 2019). Menurut Messerschmidt (2012), hegemoni maskulinitas juga turut andil di mana laki-laki menunjukkan dominasi dan kekuasaannya sebagai laki-laki sehingga hal tersebut melegitimasi ideologi subordinasi global perempuan dengan laki-laki. Hegemoni maskulinitas merupakan pola praktik yang memungkinkan dominasi laki-laki atas perempuan yang dapat berlanjut. Posisi kualitas maskulin dianggap superior dibandingkan kualitas inferior yang melekat pada feminitas, hal tersebut menunjukkan bahwa adanya ketidaksetaraan gender (Messerschmidt, 2012).

Menurut Meyers (1997), media dalam memberitakan kasus kekerasan terhadap perempuan jarang mewakili korban perempuan yang aktif menolak dan membela diri. Media cenderung memberitakan mengenai korban perempuan yang pasif seperti tidak melawan atau mengambil tindakan untuk membela diri mereka. Maka dari itu istilah "korban" lebih akurat menggambarkan bagaimana berita memberitakan perempuan pada umumnya. Representasi perempuan sebagai korban kekerasan yaitu di mana perempuan dibuat rentan oleh laki-laki, namun mereka dapat dibuat aman hanya oleh lakilaki (Meyers, 1997).

Berita membingkai kekerasan terhadap perempuan untuk mendukung, mempertahankan, dan mereproduksi supremasi laki-laki dikarenakan oleh mitos budaya dan stereotipe mengenai perempuan dan laki-laki (Meyers, 1997). Melalui liputan berita mengenai kekerasan terhadap perempuan akan memunculkan dikotomi perempuan baik dan perempuan buruk, hal tersebut mencerminkan gagasan patriaki mengenai tempat dan peran perempuan yang layak (Meyers, 1997).

\section{RESEPSI AUDIENS (ENCODING-DECODING)}

Level penelitian ini terdapat pada level komunikasi massa yaitu di mana komunikasi yang dilakukan melalui media massa. Cakupan penelitian ini yaitu pada studi khalayak dengam bidang kajian gender. Penelitian ini menggunakan Teori Resepsi Audiens yang dikemukakan oleh Stuart Hall yang membahas mengenai pemaknaan audiens dalam memaknai sebuah teks yang disajikan oleh media.

Menutut Livingstone, sebagaimana dikutip dalam Nightingale (2011), dalam definisi yang mencakup sebagian besar penelitian mengenai khalayak yang terkait dengan studi media dan budaya, menggambarkan resepsi audiens sebagai kerja yang berfokus pada hubungan interpretatif antara audiens dan media, di mana hubungan ini dipahami dalam konteks etnografi (Nightingale, 2011).

Hall, seperti yang dikutip dalam Yusuf \& Liman (2015), mengatakan bahwa dalam proses komunikasi terdapat encoding oleh media dan decoding yang dilakukan oleh audiens. Encoding merupakan proses membuat pesan yang sesuai dengan menerjemahkan kode tertentu, sedangkan decoding adalah proses menerjemahkan kembali kode untuk memaknai sebuah pesan (Yusuf \& Liman, 2015). Audiens berperan aktif dalam memaknai dan menginterpretasikan pesan yang mereka terima, di mana makna yang dipahami dapat berbeda dengan makna yang terkandung dalam pesan tersebut (Pertiwi, Ri'aeni, \& Yusron, 2020).

Menurut Hall (1993), tanggapan dari audiens tidak dapat digeneralisasikan apakah itu salah atau benar. Pemaknaan dalam resepsi audiens terdapat tiga macam yaitu Dominant Hegemonic Position, Negotiated Position, dan Oppositional Code. Pertama, Dominant Hegemonic Position merupakan posisi dominan di mana hasil decoding teks pada diri audiens sesuai dengan encoding dan pemaknaan tersebut terinstitusionalisasikan dalam diri mereka. Kedua, Negotiated Position merupakan posisi gabungan audiens ketika tidak menyepakati keseluruhan dari encoding, namun juga tidak menolak. Ketiga, Oppositional Code merupakan posisi oposisi di mana menolak encoding yang telah diberikan oleh teks (Hall, 1993). 


\section{KAJIAN PUSTAKA}

Penelitian yang serupa dengan penelitian ini yaitu dengan jurnal berjudul "Studi Resepsi Khalayak terhadap Pemberitaan Syariat Islam pada Kompas.com" yang ditulis oleh Uswatun Nisa pada tahun 2017. Penelitian tersebut mendapatkan hasil penelitian bahwa setiap pembaca memiliki interprestasi yang berbeda terhadap pemberitaan yang sama sesuai dengan kerangka pengetahuan dan pengalaman dari masing-masing informan. Posisi pembaca dari informan lebih dominan pada oppositional reading dibandingkan posisi dominant reading di mana perbedaan pemaknaan dipengaruhi oleh faktor sosiologis, psikologis, dan media habit dari masing-masing informan (Nisa, 2017).

Persamaan dari penelitian ini dengan penelitian tersebut yaitu meneliti mengenai resepsi audiens terhadap sebuah pemberitaan dengan menggunakan Teori Resepsi Audiens oleh Stuart Hall dengan metode penelitian kualitatif. Sedangkan perbedaannya di mana penelitian terdahulu mengenai pemberitaan syariat Islam pada Kompas.com dan pada penelitian ini mengenai pemberitaan korban pelecehan seksual Baiq Nuril di berbagai media.

\section{METODE PENELITIAN}

Penelitian ini mengkaji mengenai resepsi audiens atas kekerasan seksual terhadap pemberitaan korban pelecehan seksual Baiq Nuril sehingga penelitian ini menggunakan paradigma kritis dengan menggunakan metode kualitatif. Menurut Kriyantono (2010), penelitian kualitatif bertujuan untuk menjelaskan fenomena dengan sedalam-dalamnya dan pengumpulan data sedalam-dalamnya. Penelitian ini menggunakan jenis penelitian deskriptif.

Teknik sampling yang digunakan yaitu purposive sampling kepada dua informan yaitu informan pertama dan ketiga dengan karakteristik informan penelitian ini yaitu khalayak yang pernah membaca mengenai pemberitaan kasus tersebut dan memiliki pemahaman atas tema penelitian ini. Informan pertama yaitu Fatwa, seorang laki-laki pekerja yang memiliki pemahaman dalam bidang sosial dan pernah mengikuti pemberitaan kasus Baiq Nuril pada MetroTV. Informan ketiga yaitu Singgih, seorang laki-laki yang memiliki pemahaman dalam bidang hukum di mana informan ini merupakan Dosen Hukum dan pernah membaca pemberitaan pada website Kompas.com. Peneltian ini juga menggunakan teknik snowball sampling kepada dua informan yaitu informan kedua dan keempat di mana informan kedua informan ini dipilih berdasarkan informasi dari informan pertama yaitu Vanny, seorang ibu rumah tangga yang pernah menonton tayangan kasus Baiq Nuril pada program gelar wicara Mata Najwa di Trans7, sedangkan informan keempat yaitu Eva, seorang perempuan yang memiliki pemahaman dalam bidang gender yang merupakan Dosen Sosiologi yang juga pernah mengikuti pemberitaan kasus Baiq Nuril tersebut pada RCTI.

Teknik pengumpulan data melalui in-depth interview (wawancara mendalam) kepada informan yang telah ditentukan. Wawancara dilakukan secara tatap muka kepada masing-masing informan berdasarkan waktu yang telah disepakati bersama. Pengumpulan Selain itu, data pendukung diperoleh dari berita kasus Baiq Nuril pada pemberitaan di MetroTV, tayangan Mata Najwa pada episode Baiq Nuril, teks berita pada Kompas.com, dan pemberitaan di RCTI.

Sedangkan teknik analisis data menggunakan model Miles \& Huberman (1994) dengan melalui tiga tahapan yaitu reduksi data (data reduction), penyajian data (data display), dan penarikan kesimpulan (conclusion drawing). Reduksi data dilakukan dengan memilih dan menyederhanakan transkrip wawancara dengan menghilangkan parabahasa dari informan dan suasana saat dilakukannya wawancara. Selanjutnya penyajian data dilakukan dalam bentuk berupa narasi dari hasil transkrip wawancara sehingga mendapatkan hasil analisis bahwa informan termasuk ke dalam kategori posisi penafsiran yang mana. Sedangkan penarikan kesimpulan dengan mengambil informasi penting dalam penelitian secara garis besar. Uji validitas pada penelitian ini menggunakan teknik triangulasi teori di mana analisis data akan diuji dengan teori yang berkaitan dengan kekerasan seksual dan encodingdecoding Stuart Hall dari paradigma kritis. 


\section{HASIL DAN PEMBAHASAN}

HASIL

\section{Resepsi Audiens terhadap Keberpihakan Media}

Keberpihakan yang dilihat oleh informan memiliki berbagai macam bentuk, misalnya informan Singgih yang memaknai bahwa Kompas.com dalam melakukan pemberitaan mengenai kasus Baiq Nuril telah berimbang dengan tidak menyudutkan salah satu pihak saja, namun juga memberikan informasi lengkap mengenai kronologi pemberitaan.

Saya kira informatif. Tidak tendentious, artinya tidak ingin menyudutkan salah satu pihak seolah-olah misalkan si pelaku, si kepala sekolah itu hanya dia yang bersalah. Tidak seperti itu, tetapi dari kronologi itu kita bisa mempunyai pemahaman yang lengkap menurut saya pribadi. Sehingga kita dalam memaknai berita itu, kita bisa punya pemahaman yang cukup untuk menilai dari perspektif mana. (Singgih)

Menurut Singgih, pemberitaan di Kompas.com mengenai kasus kekerasan seksual juga telah mematuhi etika jurnalistik yaitu presumption of innocence dengan tidak menyebutkan dengan jelas nama terdakwa sebelum dinyatakan benar-benar bersalah dalam kasus tersebut.

Kemudian pada tindakan yang dilakukan oleh Baiq Nuril, Singgih memaknai bahwa Baiq Nuril ingin membuktikan bahwa dirinya tidak memiliki hubungan spesial dengan kepala sekolah dan juga rekaman tersebut digunakan sebagai bukti kekerasan seksual yang dialaminya. Hal tersebut menunjukkan bahwa tindakan Baiq Nuril sebagai korban yang membela diri dan ingin membuktikan bahwa dirinya tidak bersalah dengan melakukan perekaman tersebut. Namun, apabila mengalami kasus kekerasan seksual sebaiknya menyampaikan kepada pihak terkait misalnya Komnas Perempuan dan Koalisi Perempuan untuk mendapatkan dukungan baik secara psikis, moril, dan hukum. Pada umumnya perempuan kesulitan mengungkapkan kekerasan yang dialaminya karena menganggap hal tersebut sebagai aib.

Selanjutnya, informan Vanny memaknai bahwa pemberitaan di media yaitu Mata Najwa informatif dan cukup terbuka membahas kasus yang sensitif secara detail dan mendalam dengan mendatangkan berbagai sumber, sehingga tidak hanya menyalahkan Baiq Nuril, namun juga membahas dari sisi Baiq Nuril. Maka dari itu peran media cukup membantu Baiq Nuril untuk mendaparkan keadilan dari MA, hukum, dan dari bantuan pemerintah. Tujuan mendatangkan berbagai pihak yaitu untuk mendapatkan kebenaran informasi dari banyak pihak, khusunya pihak Baiq Nuril dan kuasa hukumnya serta pihak pemerintah yaitu Juru Bicara MA dan Menteri Komunikasi dan Informatika mengenai klarifikasi bagaimana proses perkara tersebut di dalam MA yang akhirnya MA menyatakan bahwa Baiq Nuril bersalah. Media juga menjelaskan kronologi kasus kekerasan seksual verbal yang dialami oleh Baiq Nuril.

Menurut Vanny, media dalam kasus kekerasan seksual tidak pernah memberitakan mengenai pelaku kekerasan seksual, namun media justru ramai memberikan mengenai korban kekerasan seksual saja.

Harusnya pelakunya yang si A nya itu kenapa gak disorot media, kenapa si A nya itu malah ditutup-tutupi, kenapa yang pelakunya itu malah seolah-olah nggak pernah disorot media. Kita nggak pernah tahu kan si kepala sekolah itu kayak apa sih orangnya, kenapa malah Baiq Nuril yang istilahnya menjadi korbannya yang malah jadi sasarannya, terus malah jadi yang disalahkan, malah kena Undang-Undang ITE itu. (Vanny)

Pada tindakan yang dilakukan Baiq Nuril, Vanny memaknai bahwa Baiq Nuril memang tidak ada niat untuk melaporkan dan hanya merekam karena merasa risih dengan tindakan kepala sekolah yang dilakukan secara berkali-kali tersebut. Baiq Nuril juga tidak melaporkan kekerasan seksual yang dialaminya karena takut akan kehilangan pekerjaannya. 
Informan Fatwa memaknai bahwa media yaitu MetroTV secara implisit dalam melakukan pemberitaan berusaha untuk memunculkan empati dari masyarakat sehingga membentuk oponi agar masyarakat peduli terhadap kasus tersebut dan membuat gerakan-gerkan yang mendukung Baiq Nuril.

Menurut Fatwa, media hanya memberitakan kasus kekerasan seksual untuk menjadi konsumsi saja, hanya dari kasus muncul hingga kasus tersebut selesai, namun proses preventif dan edukasi dari media belum maksimal.

Alangkah baiknya ada upaya preventif dari media itu bahwa media berperan dalam melakukan sosialisasi dalam melakukan informasi, mengedukasi masyarakat bahwa di sekitar kita itu masih banyak pelaku-pelaku kekerasan seksual sehinga untuk semua kalangan baik anak-anak maupun perempuan itu juga harus waspada terhadap adanya kekerasan seksual itu. Jadi media itu harus dapat sebagai fungsi edukasi di masyarakat. (Fatwa)

Fatwa memaknai bahwa tindakan Baiq Nuril yaitu Baiq Nuril belum memiliki pemahaman dalam pelaporan mengenai rekaman percakapan telepon tersebut, di mana seharusnya Baiq Nuril melaporkan hal tersebut melalui prosedur yang tepat yaitu kepada pihak yang berwenang dalam hukum seperti Komnas Perempuan, Lembaga Swadaya Masyarakat (LSM), Polisi, dan sebagainya untuk medapatkan dukungan serta perlindungan.

Informan Eva memaknai bahwa pemberitaan di media yaitu RCTI cukup obyektif dengan memberikan kronologi yang jelas dalam memberitakan kasus Baiq Nuril, namun masih terdapat ketimpangan gender di mana hanya satu pihak saja yang diberitakan, sedangkan pelaku kekerasan seksual itu tidak pernah dimunculkan, dan pihak yang sebenarnya menyebarkan rekaman tersebut juga tidak ditampilkan media.

Selanjutnya pada kasus kekerasan seksual, media menyebutkan inisial nama dari korban, namun media sendiri masih memunculkan identitas korban kekerasan seksual seperti alamat lengkap korban tersebut. Media juga sering kali membuat judul yang bombastis sebagai ajang promosi agar laku di pasaran.

Karena saya tahu bahwa media itu membutuhkan headline yang cukup bombastis. Kalo saya melihat media itu masih sedikit timpang, jadi masih sedikit ada perlakuan-perlakuan yang timpang gender, tidak seimbang antara laki-laki dan perempuan dalam suatu berita. (Eva)

Kemudian Eva memaknai bahwa tindakan yang dilakukan Baiq Nuril pada awalnya bukan tindakan yang tepat karena belum ada keberanian untuk melaporkan. Baiq Nuril memikirkan mengenai dampak panjang yang mungkin akan terjadi selanjutnya apabila dia melaporkan kasus tersebut, seperti bagaimana nasib anak-anaknya nanti, bagaimana apabila melaporkan maka nama Baiq Nuril sendiri akan terseret menjadi buruk, bagaimana nanti jika dia akhirnya dipecat, dan sebagainya. Namun, Baiq Nuril bukan orang yang bodoh karena dia berani merekam percakapan telepon tersebut. Baiq Nuril cukup cerdik namun tidak melaporkan pada pihak berwajib yang berhak menangani kasus tersebut.

Berdasarkan pemaknaan dari Singgih, media Kompas.com merupakan media yang berpihak atau pro pada keadilan gender dan Singgih juga sepakat dengan pemaknaan yang ditampilkan dari Kompas.com. Menurut pemaknaan dari Vanny, Mata Najwa juga merupakan media yang pro keadilan gender dan Vanny juga menyepakati pemaknaan dari pemberitaan di Mata Najwa, namun media tidak pernah memberitakan mengenai pelaku dan hanya menyoroti korban saja. Sedangkan pemaknaan dari Fatwa, media MetroTV merupakan media yang pro keadilan gender dengan berusaha memunculkan empati dari masyarakat, namun MetroTV hanya melakukan pemberitaan yang dijadikan sebagai komoditas publik. Eva juga memaknai bahwa RCTI merupakan media yang tidak sensitif terhadap keadilan gender, Eva juga mengkritik mengenai masih adanya ketimpangan gender dari pemberitaan yang dilakukan oleh RCTI. 
Memaknai keberpihakan pemberitaan di media, satu informan yaitu Singgih terdapat dalam dominant hegemonic position. Dua informan lainnya yaitu Vanny dan Fatwa berada dalam negotiated position. Sedangkan satu informan lainnya yaitu Eva berada dalam posisi oppositional code.

\section{Resepsi Audiens terhadap Keterlibatan Pemerintah}

Keterlibatan pemerintah yang dilihat oleh informan menghasilkan bentuk yang bermacam-macam, misalnya informan Fatwa yang memaknai bahwa MA telah melakukan vonis sesuai dengan aturan yang ada pada undang-undang. Pemerintah dinilai cukup obyektif dalam melakukan penanganan terhadap kasus tersebut dan Presiden sendiri juga terlibat dalam kasus tersebut yaitu mendukung dengan hak amnesti untuk membebaskan Baiq Nuril.

Pemerintah juga tidak tinggal diam, artinya pemerintah juga melakukan pengumpulan-pengumpulan fakta berkaitan dengan hal tersebut, meskipun Baiq Nuril dijerat dengan UU ITE tetapi pemerintah tetap mendukung dengan hak-hak amnestinya untuk membebaskan Baiq Nuril itu. (Fatwa)

Informan Eva juga memberikan pemaknaan yang sama, di mana MA telah bertindak pada posisinya. MA tidak hanya mendengarkan dari satu sisi saja, namun juga mendengarkan dari pihak lain seperti Komnas Perempuan dan Anggota DPR. Lembaga pemerintah lainnya juga ikut terlibat dalam kasus tersebut seperti Komnas Perempuan, Kementerian Pemberdayaan Perlindungan Perempuan dan Perlindungan Anak (PPPA), serta Kementerian Pendidikan dan Kebudayaan (Kemendikbud) baik dalam upaya pendampingan maupun masukan dalam kasus Baiq Nuril ini. Selain itu, Presiden juga terlibat dengan memberikan amnesti yang berdasarkan pada pertimbangan kemanusiaan dan empati.

Saya kira sudah semestinya dan saya yakin bahwa beliau tidak segampang menjatuhkan amnesti. Dalam pertimbangan dengan landasan hukum yang ada, dari segi kemanusiaan, dari segi sosial nah mungkin beliau juga ada pertimbangan kemanusiaan kemudian empati dan sebagainya. Saya kira sudah masuk di situ Presiden. (Eva)

Informan Vanny memaknai bahwa seharusnya MA dapat bertindak adil dengan tidak hanya melihat Baiq Nuril bersalah karena melanggar UU ITE dari kasus tersebut, karena Baiq Nuril sendiri merupakan korban pelecehan seksual yang justru mendapatkan hukuman. MA seharusnya juga melihat Baiq Nuril sebagai seorang ibu yang membutuhkan keadilan hukum. Kemudian, Vanny juga memaknai bahwa Presiden telah memberikan perhatian dengan memberikan amnesti pada kasus ini.

Harusnya MA adil, nggak melihat Baiq Nuril sebagai korban aja tapi juga dia seorang ibu yang membutuhkan keadilan hukum. Jadi harus nggak cuman disalahkan juga. Jadi harus bener-bener diselidiki gak cuman dari Baiq Nuril, kan sebenernya itu Baiq Nuril itu bukan pelaku ya, kenapa dia malah bersalah gitu lho. (Vanny)

Sedangkan informan Singgih memaknai bahwa berdasarkan dari sisi feminist jurisprudence seharusnya MA lebih memperhatikan perspektif gender karena perempuan termasuk dalam kategori kaum yang rentan sebagai korban dari sebuah tindak pidana. Selanjutnya, Singgih tidak sepakat dengan pernyataan Presiden mengenai pemberian amnesti. Presiden menyatakan bahwa dapat memberikan amnesti, namun lebih baik lakukan upaya Peninjauan Kembali (PK) terlebih dulu. Amnesti merupakan semacam pengampunan yang diberikan negara untuk tujuan tertentu setelah terpidana tersebut dinyatakan benar-benar bersalah, padahal Baiq Nuril selama ini melakukan upaya perlawanan hingga ke tingkat kasasi hanya untuk membuktikan bahwa dirinya tidak bersalah. Sehingga amnesti menjadi saling berlawanan dan upaya mencari amnesti kurang tepat. 
Nah, apakah mau si Baiq Nuril ini dinyatakan sebagai yang bersalah, ya kan? Sehingga upaya mencari amnesti ini menurut saya kurang tepat, yang perlu dilakukan adalah lakukan dulu upaya Peninjauan Kembali. Cuman memang kekhawatirannya Peninjauan Kembali kan juga nanti ujung-ujungnya di MA. Kalau di tingkat kasasi aja MA-nya sudah salah menerapkan hukum, apakah tidak mungkin di-PK nanti Mahkamah Agung juga masih dengan putusan yang sama? (Singgih)

Berdasarkan pemaknaan dari Fatwa, pemerintah ikut terlibat dalam kasus kekerasan seksual dengan memberikan dukungan dalam penegakan hukum. Eva juga memaknai bahwa keterlibatan pemerintah dalam kasus tersebut melalui banyak sisi seperti Lembaga Hukum, Lembaga Pemerintahan, Kementerian, bahkan Presiden. Informan Vanny memaknai bahwa pemerintah cukup terlibat dalam kasus tersebut dengan memberikan perhatian amnesti, namun dalam proses penegakan hukum, MA seharusnya lebih bertindak adil agar korban tidak menjadi pihak yang justru mendapatkan hukuman dari kasus yang dialaminya. Sedangkan Singgih memberikan pemaknaan bahwa keterlibatan pemerintah dalam kasus kekerasan seksual dinilai tidak sensitif terhadap gender, masih perlu adanya pertimbangan mengenai feminist jurisprudence yang melihat perspektif gender dalam penegakan hukum.

Memaknai keterlibatan pemerintah, dua informan yaitu Fatwa dan Eva terdapat dalam dominant hegemonic position. Informan Vanny berada dalam negotiated position, sedangkan informan Singgih berada dalam posisi oppositional code.

\title{
Resepsi Audiens berdasarkan Latar Belakang
}

Informan dalam memberikan pemaknaan mengenai kekerasan seksual dan kekerasan berbasis gender berdasarkan pada latar belakang mereka masing-masing, baik melalui pengalaman maupun pengetahuan. Informan dalam memaknai kekerasan seksual terdapat beberapa macam, seperti informan Fatwa yang memaknai bahwa kekerasan seksual sekarang ini sangat meresahkan. Hal tersebut dikarenakan belum ada payung hukum yang jelas dan seharusnya dapat diimplementasikan dari tingkat bawah hingga atas agar pelaku kekerasan seksual mendaparkan hukuman sesuai dengan aturan-aturan yang berlaku. Sehingga hal tersebut menjadi dilematik apabila ada korban yang ingin melaporkan kasus yang dialaminya. Perlu ada perlindungan dan dukungan terhadap perempuan dari lembaga khusus yang berkaitan dengan kekerasan seksual sehingga korban tidak takut untuk melapor.

Fatwa memberikan pemaknaan bahwa posisi perempuan dalam kasus kekerasan seksual yaitu sangat dirugikan karena perempuan dieksploitasi dari kasus mereka sendiri. Perempuan dianggap sebagai pemicu terjadinya kekerasan seksual seperti mengenakan pakaian yang mengundang hasrat laki-laki, padahal hal tersebut juga dikarenakan laki-laki tersebut yang kurang memiliki etika. Maka dari itu perlu adanya aturan yang memberikan hukuman bagi pelaku kekerasan seksual serta perlu adanya kehati-hatian dari perempuan agar tidak menimbulkan pola-pola yang memicu adanya kekerasan seksual.

\begin{abstract}
Artinya perlu ada sebuah aturan atau undang-undang dalam memberikan hukuman bagi pelaku kekerasan seksual dan kekerasan seksual ini juga harus dimaknai bahwa harus ada kehati-hatian dari si perempuan, yang artinya perempuan di zaman sekarang kan banyak yang malem-malem itu masih berkeliaran dan sebagainya itu menjadi pola-pola yang menurut saya juga memicu adanya kekerasan. Malam dia bepergian sendiri dan ini sangat riskan terhadap hal-hal tersebut seperti itu. (Fatwa)
\end{abstract}

Fatwa memahami kekerasan berbasis gender berdasarkan dari pernah berkuliah di Jurusan Sosiologi dan melakukan penelitian berkaitan dengan analisis gender. Fatwa memaknai bahwa kekerasan merupakan sebuah perbuatan yang bersifat untuk melukai, di mana ada satu pihak yang dirugikan dari perbuatan itu dan gender merupakan hal yang berkaitan dengn ketimpangan antara laki-laki dan perempuan. Maka dari itu, kekerasan terhadap gender adalah sebuah perlakuan yang 
sangat mendiskreditkan perempuan sebagai korban, di mana perempuan sebagai hal yang dapat dieksploitasi baik dari tubuh, tenaga, maupun waktu.

Selanjutnya, informan Vanny memaknai bahwa sekarang ini kekerasan seksual bukan hanya dalam bentuk fisik saja seperti sentuhan dan lainnya, namun juga dalam bentuk verbal seperti komentar seksual dan sebagainya. Selain itu, kasus kekerasan seksual kebanyakan menimpa perempua dan jarang menimpa laki-laki. Banyak kasus kekerasan seksual di Indonesia seperti pada transportasi umum di dalam angkot misalnya, di mana hal tersebut sangat dekat dengan keseharian kita. Kemudian upaya untuk menangani kekerasan seksual tidak hanya dari pemerintah karena pemerintah hanya memfasilitasi seperti dengan memberikan ruang publik, namun ditambah dengan adanya empati dan simpati dari orang lain, menghargai sesama, dan hal pertama yang harus dimulai adalah dari diri sendiri. Kita harus dapat membentengi diri sendiri agar terhindar dari kekerasan seksual.

Vanny memberikan pemaknaan bahwa posisi perempuan selalu menjadi korban karena perempuan selalu dijadikan sebagai objek. Seperti objek dalam kekerasan seksual baik secara fisik maupun verbal. Vanny memahami kekerasan berbasis gender berdasarkan dari membaca di media dan tidak terlalu mengikuti hal-hal yang berkaitan mengenai gender. Vanny mendapatkan pengetahuan mengenai gender hanya sekilas membaca misalnya ketika ada kekerasan seksual yang sedang diberitakan di media televisi atau media massa lainnya.

Kalo saya nggak terlalu ini ya mengikutinya tentang gender, maksudnya secara spesifik gender, nggak, cuman sekilas membaca, misalnya kalo ada kekerasan seksual dan sebagainya. Jadi belum begitu ini sih (paham) untuk masalah gender. (Vanny)

Sedangkan informan Singgih memaknai bahwa kekerasan seksual tidak hanya secara fisik namun juga beragam bentuknya seperti tindakan pelecehan seksual secara psikis bahkan fisik. Sebuah siulan atau colekan saja termasuk dalam bentuk pelecehan seksual karena telah menimbulkan perasaan tidak menyenangkan atau tidak nyaman dari perempuan. Kasus kekerasan seksual di Indonesia sekarang ini lebih disebabkan karena orang-orang terutama remaja yang tidak cukup bijaksana dalam berkomunikasi melalui internet. Perlu adanya peran dari orang tua, pemerintah, Lembaga Pendidikan, dan rohaniawan dalam mengedukasi. Selain itu dalam meminimalisir kekerasan seksual dapat melalui lembaga seperti Komnas Perempuan, Koalisis Perempuan, dan lainnya yang dapat memberikan perlindungan pada korban.

Posisi perempuan dalam kasus kekerasan seksual menurut pemaknaan dari Singgih, seringkali perempuan menjadi pihak yang rentan dan lemah karena seringkali menjadi korban pelecehan seksual. Perempuan memiliki dua kualitas di mana perempuan dapat menjadi korban atas perbuatannya sendiri atau memang murni atas perbuatan orang lain. Hal tersebut kembali ke bagaimana perempuan menjaga dirinya karena tidak ada perlindungan terbaik kecuali menjaga diri sendiri.

Perempuan itu khususnya di Indonesia selama ini kan seolah-olah menjadi pihak yang selalu dipandang lemah. Sehingga di dalam perjalanan hidup seorang perempuan, itu sudah menjadi hal yang lumrah kalo perempuan itu adalah pihak yang lemah. Tapi hari ini perempuan saya kira posisinya jauh lebih kuat. (Singgih)

Singgih memahami kekerasan berbasis gender berdasarkan dari pernah berkuliah di Fakultas Hukum dan mendapat mata kuliah mengenai victimology yang khusus mempelajari tentang korban dan krimonologi yang mempelajari mengenai bagaimana sebuah tindakan kriminalitas itu bisa terjadi. Kekerasan berbasis gender pada umumnya yaitu perempuan sangat rentan terkait dengan tindak pidana pornografi, kesusilaan, perzinaan, dan pemerkosaan. Perempuan khususnya di Indonesia selama ini seolah-olah menjadi pihak yang selalu dipandang lemah. Namun hari ini perempuan posisinya jauh lebih kuat. 
Kemudian informan Eva memberikan pemaknaan terhadap kekerasan seksual yaitu kekerasan seksual sekarang ini bukan hanya bertambah jumlahnya, namun bertambah macamnya. Kekerasan seksual tidak hanya menimpa pada hari itu saja, namun dalam jangka panjang seperti trauma, pengobatan, dan sebagainya. Sekarang ini telah banyak lembaga yang bersedia mendampingi, sosialisasi mengenai kekerasan, dan adanya keberanian perempuan untuk mengungkapkan kekerasan seksual yang dialaminya.

Eva juga memaknai posisi perempuan dalam kasus kekerasan seksual masih sebagai korban. Bahkan sering kali perempuan yang menjadi korban mengalami viktimisasi sekunder baik dari berbagai pihak, misalnya pihak berwajib dalam mengajukan pertanyaan kepada korban yang cenderung menyalahkan korban. Sehingga korban tersebut menjadi korban untuk kedua kalinya, maka perlu adanya empati dari pihak lain. Meskipun kasus kekerasan meningkat, namun perempuan telah mulai berani untuk mengungkapkan kekerasan yang dialaminya. Bahkan di Solo misalnya telah ada konsorsium antara Rumah Sakit, LSM, Kepolisian, dan pemerintah untuk pelaporan, pendampingan, pemberian modal bagi yang tidak mampu, dan sebagainya. Sehingga perempuan lebih berdaya dengan dilakukannya pendampingan serta mapan dalam ekonomi.

Jadi sudah ada (konsorsium) seperti itu, nah inilah yang dibutuhkan sebenarnya. Supaya perempan jadi lebih berdaya. Jadi kalo saya sudah lapor, saya lari ke rumah sakit ada visumnya, ke kepolisian sudah ada (laporan), kemudian ke LSM atau pemerintah dilakukan pendampingan dan pada akhirnya perempuan menjadi lebih mapan ekonominya. (Eva)

Eva memahami kekerasan berbasis gender berdasarkan dari proses belajar dengan pernah mengikuti berbagai seminar, dari pengalaman, serta pembelajaran pada pertemuan-pertemuan tertentu. Eva sekarang ini menjadi Dosen Sosiologi yang mengajar mengani Mata Kuliah Analisa Gender dan sedang menempuh Pendidikan S3 dengan studi pendalaman disertasi mengenai Anak dan Pemberdayaan Masyarakat. Eva juga tergabung dalam Pusat Studi Gender di Universitas. Menurut Eva, kekerasan berbasis gender merupakan suatu tindakan yang menimpa salah satu jenis kelamin dengan pelakunya juga salah satu jenis kelamin yang mengakibatkan suatu keadaan tertentu yanda dapat menyebabkan luka baik secara fisik, non fisik atau verbal, ekonomi, bahkan hingga menyebabkan korban meninggal.

\section{PEMBAHASAN}

Pada resepsi audiens terhadap keberpihakan media, peneliti menemukan bahwa informan Singgih berada pada posisi dominan ketika informan memberikan pemaknaan mengenai pemberitaan kekerasan seksual sesuai seperti yang ingin ditampilkan oleh media tersebut. Media berhasil menggiring informan untuk sepakat dengan ideologi dominan yang digunakan oleh media. Selanjutnya, informan Vanny dan Fatwa berada dalam posisi negotiated karena informan menyepakati apa yang ingin ditampilkan media yang mereka konsumsi, namun informan memahami bagaimana media mengkonstruksikan berita dan juga melihat dari perspektif gender, sehingga informan dapat mengkritik mengenai pemberitaan yang dilakukan oleh media, misalnya media dalam melakukan pemberitaan kekerasan seksual hanya dijadikan sebagai konsumsi publik. Sedangkan informan Eva pada posisi oposisi karena informan memahami mengenai bagaimana media mengkonstruksikan berita dan juga memaknai bahwa media tidak sensitif terhadap gender karena masih terdapat ketimpangan di dalam pemberitaan media.

Menurut pemahaman informan Fatwa dan Vanny, media dalam membuat pemberitaan suatu kasus, khususnya kasus kekerasan seksual seringkali menggiring audiens untuk berpihak mengikuti pemberitaan di media tersebut, meskipun tujuan pemberitaan dari media adalah untuk menyampaikan informasi yang benar kepada khalayak. Menurut Satiti (2010), media tidak netral dalam 
mendefinisikan realitas namun sesuai dengan kepentingan media itu sendiri. Seperti kelompok dan ideologi mana yang dominan, maka itulah yang akan tampil dalam suatu pemberitaan (Satiti, 2010).

Informan Eva memaknai bahwa media cenderung membuat judul headline berita yang bombastis demi menarik perhatian audiens. Bahkan sering kali adanya ketimpangan gender yang dilakukan media dalam membuat suatu pemberitaan, di mana fokus pemberitaan hanya pada korban dan tidak pernah memberitakan mengenai pelaku kekerasan seksual. Hal ini menunjukkan bahwa berita hanya dijadikan sebagai komoditas untuk menarik perhatian publik (Geruh, Dwi N., \& Basuki, 2010), selain itu perempuan juga dijadikan sebagai komoditas bahkan objek yang dieksploitasi (Sutarso, 2012). Media juga memberitakan bahwa seolah-olah korban tidak memiliki perlawanan terhadap kasus kekerasan seksual yang menimpanya (Meyers, 1997).

Berdasarkan pemaknaan informan Singgih, media telah mematuhi Kode Etik Jurnalistik Pasal 3 ayat (d), yaitu asas praduga tak bersalah (presumption of innocence) adalah prinsip tidak menghakimi seseorang dengan tidak menyebutkan nama pelaku sebelum terbukti menjadi terdakwa dalam kasus tersebut. Namun, berbeda dengan informan Eva yang memaknai bahwa media masih menyebutkan identitas korban seperti alamat lengkap korban di mana hal tersebut berarti melanggar Kode Etik Jurnalistik Pasal 5 di mana wartawan tidak menyebutkan dan menyiarkan identitas korban kejahatan susila (Dewan Pers, 2013).

Pada kasus kekerasan seksual, adanya relasi kuasa menjadi salah satu penyebab kekerasan tersebut terjadi. Dalam kasus Baiq Nuril, yaitu adanya relasi kuasa antara kepala sekolah sebagai pihak superior dan guru honorer sebagai pihak inferior menunjukkan bahwa adanya ketidaksetaraan gender (McLaughlin, Uggen, \& Blackstone, 2012). Sehingga korban takut dan tidak melaporkan kekerasan yang menimpanya karena akan menimbulkan dampak kehilangan pekerjaannya.

Menurut pemaknaan informan Eva dan Singgih, korban tidak melaporkan kasusnya karena menganggap kekerasan yang dialaminya merupakan sebuah aib. Korban kekerasan seksual tidak melaporkan kasusnya terkait dengan adanya ancaman terhadap harga diri dan risiko viktimisasi sekunder. Individu akan menghindar dari berbagi stigma karena membuat mereka menyalahkan diri sendiri (self-blame), menimbulkan rasa malu, dan takut akan adanya penilaian negatif dari orang lain (Keplinger et al., 2019).

Selanjutnya berdasarkan pemaknaan dari informan, tindakan Baiq Nuril dianggap cerdik karena merekam percakapan telepon untuk melindungi dirinya dan digunakan sebagai bukti adanya kekerasan seksual yang dialaminya. Namun, korban kekerasan seksual tidak melaporkan kekerasan yang menimpanya karena korban tidak mengetahui prosedur yang ada untuk melaporkan kasus tersebut sehingga korban lebih memilih diam. Padahal, suara dari korban sangat penting baik untuk diri korban sendiri maupun orang lain. Pentingnya suara dari korban kekerasan seksual yaitu untuk meningkatkan pengetahuan orang lain mengenai kekerasan seksual, melindungi perempuan dari dampak negatif kekerasan seksual, dan dengan bersuara berarti mereka tidak sendirian dalam menghadapi kekerasan seksual, serta mendapatkan perlindungan dari orang lain (Keplinger et al., 2019).

Pada resepsi audiens terhadap keterlibatan pemerintah, peneliti menemukan bahwa informan Eva dan Fatwa berada pada posisi dominan ketika informan memaknai pemberitaan di mana pemerintah telah terlibat secara dominan dalam kasus kekerasan seksual. Sedangkan, informan Vanny berada pada posisi negotiated karena menyepakati keterlibatan pemerintah, namun tidak sepakat dengan penegakan hukum yang seharusnya dapat bertindak adil dalam memutus kasus Baiq Nuril. Informan Singgih berada pada posisi oposisi karena pemahaman informan yang luas mengenai proses penegakan hukum dengan memperhatikan perspektif gender.

Berdasarkan pemaknaan dari informan, negara seharusnya turut hadir dalam keadilan gender, seperti pada kasus kekerasan seksual yang mengharuskan pemerintah untuk ikut terlibat di dalamnya. Negara bertanggungjawab dalam bertindak demi penghapusan kekerasan seksual melalui uji tuntas. Standar uji tuntas digunakan sebagai alat bagi pemegang hak untuk meminta pertanggungjawaban 
kepada negara. Sementara hukum, kebijakan dan sumber daya sangat penting untuk mengatasi kekerasan terhadap perempuan (Manjoo, 2013).

Negara memiliki tanggungjawab dalam tingkat sistemik dan individu. Pada tingkat sistemik, menciptakan sistem dan struktur yang baik serta efektif untuk mengatasi akar penyebab dan konsekuensi dari kekerasan terhadap perempuan, sedangkan tanggungjawab tingkat individu yaitu tanggungjawab negara untuk memberikan langkah-langkah efektif pencegahan, perlindungan, hukuman, dan reparasi bagi setiap korban (Manjoo, 2013). Negara seharusnya terlibat dalam kasus kekerasan seksual, baik mulai dari tahap pencegahan seperti sosialisasi dengan edukasi mengenai kekerasan seksual sehingga membuat orang-orang lebih sadar dan waspada. Kemudian pada tahap pendampingan dan perlindungan korban, mengajak agar korban yang mengalami kekerasan tersebut bersedia bersuara, mendukung mereka bahwa mereka tidak sendirian menghadapi ini, dan selanjutnya membantu korban dalam pelaporan hukum kasus tersebut. Pada tahap akhir yaitu tahap pemulihan dengan membantu korban agar tidak trauma dengan kejadian yang telah menimpanya dan membantu korban untuk lebih kuat.

Menurut informan, pada kasus kekerasan seksual negara telah terlibat dominan dalam upaya perlindungan korban melalui lembaga pemerintahan yang ada seperti Komnas Perempuan misalnya dan pemberian amnesti pada korban kekerasan seksual Baiq Nuril. Negara seharusnya lebih melindungi korban kekerasan seksual dengan adanya payung perlindungan hukum. Namun, belum ada hukum di Indonesia yang spesifik mengatur mengenai kasus kekerasan seksual, di mana pelaku kekerasan seksual hanya dijerat pasal pencabulan dalam delik kejahatan kesusilaan (Ramdhani, 2017).

Peneliti tidak menemukan adanya pengalaman mengenai kekerasan seksual yang dialami informan. Namun, informan memberikan pemaknaan yang berbeda berdasarkan dari perspektif mereka masingmasing, pendidikan, gender, serta peran sosial mereka. Informan Fatwa memaknai kekerasan berbasis gender berdasarkan dari penelitian yang pernah dilakukan sewaktu kuliah berkaitan dengan Analisa Gender. Berbeda dengan informan Vanny yang merasa dirinya minim dan tidak banyak paham secara mendalam mengenai kekerasan berbasis gender. Vanny memahami kekerasan berbasis gender hanya kekerasan dalam bentuk fisik saja, sebelum adanya pemberitaan media mengenai kasus Baiq Nuril di mana kekerasan ternyata juga dalam bentuk verbal.

Selanjutnya, informan Singgih memaknai kekerasan berbasis gender berdasarkan dari pernah berkuliah di Fakultas Hukum dan mempelajari mengenai Mata Kuliah Victimology dan Kriminologi serta peran sosialnya sebagai seorang Dosen Hukum. Sedangkan informan Eva memiliki pemaknaan mengenai kekerasan berbasis gender yang luas yang didapatkannya dari seminar, pendidikan, dan peran sosialnya sebagai seorang Dosen Sosiologi yang mengampu Mata Kuliah Analisa Gender.

Terdapat pemaknaan dari informan laki-laki di mana kekerasan terhadap perempuan bukan murni dari kesalahan orang lain. Perempuan dapat menjadi korban atas perbuatannya sendiri atau memang murni atas perbuatan orang lain. Meskipun laki-laki memang seharusnya lebih menghormati perempuan, namun perempuan juga harus berhati-hati menjaga diri agar tidak menimbulkan polapola yang memicu adanya kekerasan seksual. Seperti penelitian yang dilakukan oleh Nilan, Demartoto, Broom, \& Germovet (2014), yang memberikan hasil penelitian salah satunya yaitu persepsi laki-laki yang cenderung menyalahkan perempuan jika ada laki-laki yang melakukan kekerasan terhadap perempuan tersebut (Nilan et al., 2014).

Salah satu informan perempuan juga memaknai bahwa dalam mengatasi kekerasan seksual, di mana harus dimulai dari diri sendiri dengan membentengi diri sendiri agar terhindar dari kekerasan seksual. Namun, hal tersebut justru dapat membuat perempuan menyalahkan diri sendiri (self-blame), malu, dan takut akan adanya penilaian negatif dari orang lain apabila mereka gagal untuk menjaga dirinya sendiri (Keplinger et al., 2019).

Selama ini media memunculkan pemberitaan mengenai kekerasan berbasis gender di mana perempuan seringkali menjadi korban karena dijadikan sebagai objek pasif sedangkan laki-laki sebagai subjek aktif (Bandelli, 2017). Perempuan bahkan dianggap sebagai pemicu terjadinya kekerasan 
seksual sehingga menimbulkan victim blaming (Astuti et al., 2019). Masyarakat membentuk sistem patriarki di mana konstruksi patriarkal tersebut nyata dan tertanam dalam budaya. Ideologi patriarki mengklaim bahwa laki-laki memiliki peran maskulin, dominan, dan superior, sedangkan perempuan selalu memiliki peran bawahan atau feminin. Konstruksi budaya membentuk sistem patriarki di masyarakat yang membenarkan dan memperkuat bahwa perempuan itu lemah dan subordinat dibandingkan laki-laki (Adisa et al., 2019).

Berita di media seringkali secara tidak langsung memperingatkan perempuan mengenai tindakan dan lokasi mana yang tidak aman, mempengaruhi perempuan harus pergi ke mana, apa yang seharusnya dipakai, dan sebagainya. Sehingga hal tersebut menunjukkan bagaimana masyarakat memandang kekerasan yang dilakukan laki-laki terhadap perempuan dan karena pemberitaan di media membatasi perilaku apa yang bisa diterima dan mana yang tidak bagi laki-laki dan perempuan (Meyers, 1997). Sehingga hal tersebut menunjukkan bahwa adanya kesulitan bagi perempuan untuk mengakses ruang publik yang bebas.

Berdasarkan pemaknaan dari informan, perempuan yang menjadi korban kekerasan seksual mendapatkan pendampingan dengan adanya konsorsium antara Rumah Sakit, LSM, Kepolisian, dan pemerintah. Sehingga akan membuat perempuan menjadi lebih berdaya serta mapan dalam ekonomi. Penelitian dari Pathways of Empowerment Research Programme Consortium (RPC) menunjukkan bahwa kekerasan seksual mempengaruhi kesejahteraan perempuan yang pada akhirnya akan merusak pemberdayaan politik, sosial dan ekonomi (Hawkins, Cornwall, \& Lewin, 2011).

Pemberdayaan kepada perempuan khususnya dalam bidang ekonomi bertujuan agar perempuan dapat mengembangkan potensi dirinya sehingga dapat menyelesaikan ketimpangan sosial yang berasal dari adanya ketidaksetaraan gender (Putri, Sjamsuddin, \& Nurani, 2013). Melalui pemberdayaan perempuan, perempuan mendapatkan hak kontrol atas tubuh mereka, dapat menegaskan hak atas otonomi fisik dan perlindungan dari pelecehan agar perempuan memiliki ruang lingkup yang bebas untuk kehidupan mereka (Hawkins et al., 2011).

\section{KESIMPULAN}

Berdasarkan dari hasil penelitian ini, menunjukkan bahwa informan memunculkan pemaknaan yang beragam. Informan sepakat bahwa media menempatkan Baiq Nuril sebagai korban kekerasan seksual. Bahkan beberapa informan memaknai pemberitaan yang dilakukan media digunakan sebagai komoditas. Hal tersebut menunjukkan bahwa perempuan sebagai pihak yang rentan, di mana terdapat media yang melindungi perempuan sebagai korban dan terdapat pula pemberitaan media mengenai kasus perempuan yang digunakan untuk mendapatkan profit.

Informan memiliki respon pemaknaan atas kekerasan seksual berdasarkan latar belakang masingmasing informan yaitu perspektif, pendidikan, gender, dan peran sosial mereka. Berdasarkan pemaknaan informan, posisi perempuan pada kasus kekerasan seksual sebagai pihak yang rentan karena perempuan dianggap sebagai objek bahkan pemicu. Selain itu, terdapat media yang tidak melindungi identitas korban kekerasan seksual serta kurang terlibatnya pemerintah secara dominan karena belum adanya peraturan hukum yang spesifik mengatur mengenai kekerasan seksual.

Bagi peneliti selanjutnya dapat memberikan sudut pandang yang berbeda mengenai suatu pemberitaan tertentu di berbagai media dan dengan menggunakan informan penelitian dengan jumlah yang lebih banyak dan dengan kategorisasi peran sosial yang lebih beragam.

\section{REFERENSI}

Adisa, T. A., Abdulraheem, I., \& Isiaka, S. B. (2019). Patriarchal Hegemony: Investigating The Impact of Patriarchy on Women's Work-Life Balance. Gender in Management, 34(1), 19-33. https://doi.org/10.1108/GM-07-2018-0095

Astuti, S. W., Pradoto, D., \& Romaria, G. (2019). Victim Blaming Kasus Pelecehan Seksual (Studi Netnografi Pelecehan Seksual Terhadap Via Valen di Instagram) Victim Blaming Sexual Harassment Cases (Netnographic Study of Sexual Harassment Against Via Valen on Instagram). 
Promedia, 5(1), 145-165. http://journal.uta45jakarta.ac.id/index.php/kom/article/view/ $1625 / 1124$

Bandelli, D. (2017). Femicide, Gender and Violence (Discourses and Counterdiscourses in Italy). Switzerland: Springer Nature. https://doi.org/10.1007/978-3-319-47785-5

Dewan Pers. (2013). Pers Berkualitas, Masyarakat Cerdas. Dewan Pers. https://dewanpers.or.id/assets/ebook/buku/822-

Buku\%20Pers\%2oberkualitas\%20masyarakat\%20Cerdas_final.pdf

Hall, S. (1993). Encoding, Decoding. In S. During (Ed.), The Cultural Studies Reader (The Cultur). London: Routledge.

Hawkins, K., Cornwall, A., \& Lewin, T. (2011). Sexuality and Empowerment: An Intimate Connection (Issue October). Pathways of Women's Empowerment RPC. https://core.ac.uk/download/pdf/29136696.pdf

Geruh, F. Y., N, S. D., \& Basuki. (2010). Berita Kekerasan dalam Rumah Tangga di Harian Kompas. Jurnal Ilmu Komunikasi, 8, 13-25. http://jurnal.upnyk.ac.id/index.php/komunikasi/ article/download/65/78

Keplinger, K., Johnson, S. K., Kirk, J. F., \& Barnes, L. Y. (2019). Women at work: Changes in sexual harassment between September 2016 and September 2018. PLoS ONE, 14(7), 1-20. https://doi.org/10.1371/journal.pone.02 18313

Kriyantono, R. (2010). Teknik Praktis Riset Komunikasi. Jakarta: Kencana.

Komnas Perempuan. (2017, October 21). Kekerasan Seksual: Kenali dan Tangani! 15 Bentuk Kekerasan. Komnas Perempuan. https://www.komnasperempuan.go.id/read-news-kekerasanseksual-kenali-dan-tangani-15-bentuk-kekerasan-seksual

Komnas Perempuan. (2020, March 6). Kekerasan Meningkat: Kebijakan Penghapusan Kekerasan Seksual untuk Membangun Ruang Aman bagi Perempuan dan Anak Perempuan. Komnas Perempuan. https://www.komnasperempuan.go.id/file/pdf_file/2020/Catatan Tahunan Kekerasan Terhadap Perempuan 2020.pdf

Kompas.com. (2019a, July 9). MA dalam Perkara Baiq Nuril, Dituduh Malaadministrasi hingga Beri Masukan Amnesti. Kompas.Com. https://nasional.kompas.com/read/2019/07/09/10223411/ma-dalam-perkara-baiq-nurildituduh-malaadministrasi-hingga-beri-masukan?page $=$ all

Kompas.com. (2019b, July 30). 7 Tahun Baiq Nuril, Berawal dari Pelecehan, Tersangka UU ITE, hingga Terima Amnesti. Kompas.Com. https://nasional.kompas.com/read/2019/07/30/09564421/7-tahun-baiq-nuril-berawal-daripelecehan-tersangka-uu-ite-hingga-terima? page=all

Manjoo, R. (2013). State Responsibility to Act with Due Diligence in The Elimination of Violence against Women. International Human Rights Law Review, 2(2), 240-265. https://doi.org/10.1163/22131035-00202006

McLaughlin, H., Uggen, C., \& Blackstone, A. (2012). Sexual Harassment, Workplace Authority, and the Paradox of Power. American Sociological Review, 77(4), 625-647. https://doi.org/10.1177/0003122412451728

Messerschmidt, J. W. (2012). Engendering Gendered Knowledge: Assessing the Academic Appropriation of Hegemonic Masculinity. Men and Masculinities, 15(1), 56-76. https://doi.org/10.1177/1097184X11428384

MetroTV. (2019, July 29). Jejak Kasus Baiq Nuril [Video File]. MetroTV. https://www.metrotvnews.com/play/bJECYex5-jejak-kasus-baiq-nuril

Metrotvnews. (2019, July 6). Kronologi Kasus Baiq Nuril [Video File]. Metrotvnews. https://www.youtube.com/watch?v=1t2_kgPRwio\&t=62s

Meyers, M. (1997). News Coverage of Violence Against Women (Engendering Blame). California: Sage Publications, Inc.

Miles, M. B., \& Huberman, A. M. (1994). Qualitative Data Analysis: An Expanded Sourcebook (Vol. 251, Issue 2). California: Sage Publications, Inc.

Nightingale, V. (2011). The Handbook of Media Audiences. United Kingdom: Blackwell Publishing Ltd. https://doi.org/10.1002/9781444340525

Nilan, P., Demartoto, A., Broom, A., \& Germov, J. (2014). Indonesian Men's Perceptions of Violence Against Women. Violence Against Women, 20(7), 869-888. https://doi.org/10.1177/1077801214543383 
Nisa, U. (2017). Studi Resepsi Khalayak terhadap Pemberitaan Syariat Islam pada Kompas.com. Jurnal Komunikasi Global, 6(1), 74-89. http://www.jurnal.unsyiah.ac.id/JKG/article/view/9195

Pertiwi, M., Ri'aeni, I., \& Yusron, A. (2020). Analisis Resepsi Interpretasi Penonton terhadap Konflik Keluarga dalam Film "Dua Garis Biru." Jurnal Audiens, 1(1), 1-8. https://doi.org/10.18196/ja.1101

Putri, R. M., Sjamsuddin, S., \& Nurani, F. (2013). Pelaksanaan Pemberdayaan Perempuan Dalam Mewujudkan Keadilan dan Kesetaraan Jender di Bidang Ekonomi Pada Masyarakat Jombang. Jurnal Administrasi Publik (JAP), 1(1), 145-153. http://administrasipublik.studentjournal.ub.ac.id/index.php/jap/article/view/22/20

Ramdhani, I. (2017). Kasus Pelecehan Seksual Dalam Transportasi Umum Menurut Putusan Pengadilan Negeri Jakarta Pusat. SALAM: Jurnal Sosial Dan Budaya Syar-I, 4(1), 95-120. https://doi.org/10.15408/sjsbs.v4i1.7871

Satiti, N. L. U. (2010). Perempuan Dalam Majalah Perempuan Muslim. KomuniTi, 2(1), 30-43.

Sutarso, J. (2012). Perempuan, Kekuasaan dan Media Massa: Sebuah Studi Pustaka. KomuniTi, IV(1), 1-17. https://publikasiilmiah.ums.ac.id/bitstream/handle/11617/1827/1_JokoSutarso.pdf? sequence $=1$ \&isAllowed $=y$

Thacker, L. K. (2017). Rape Culture, Victim Blaming, and the Role of Media in the Criminal Justice System. Kentucky Journal of Undergraduate Scholarship, 1(1). http://encompass.eku.edu/kjus\%OAhttp://encompass.eku.edu/kjus/vol1/iss 1/8

Toni, A., \& Fajariko, D. (2017). Studi Resepsi Mahasiswa Broadcasting Universitas Mercu Buana Pada Film Journalism "Kill The Messenger." Jurnal Komunikasi, 9(2), 151. https://doi.org/10.24912/jk.v9i2.161

Yusuf, M. K., \& Liman, A. (2015). "Virtual Cultural Resonance" as an Evidence for "Media Effect by Consent": Notes on Media Audience Theories and Proposing New. The International Journal Of Humanities \& Social Studies, 3(11), 91-95. http://internationaljournalcorner.com/ index.php/theijhss/article/view/141158 